\title{
A retrospective of surgical pathology, care problems specific to oncological and non-oncological cases, in a year of the COVID-19 pandemic
}

\author{
O retrospectivă a patologiei chirurgicale, problemele de \\ îngrijiri specifice cazurilor oncologice şi nononcologice, \\ într-un an de pandemie COVID-19
}

\author{
Mirela Mariana Valcan ${ }^{1,2}$, Petru Mihancea', Bogdan Buhas ${ }^{1,2}$ \\ ${ }^{1}$ Facultatea de Medicină şi Farmacie, Universitatea din Oradea, România \\ ${ }^{2}$ Spitalul Clinic Județean de Urgență, Oradea, România
}

\begin{abstract}
Introduction. The activity carried out in a general surgery department is complex, the diversity of cases and comorbidities such as cardiovascular diseases, neuro-mental disorders, metabolic diseases, obesity, diabetes influence the care needs of patients. These pathologies increase risks and safety issues in the context of the COVID-19 pandemic.

Material and method. We conducted a descriptive retrospective study in which we included 749 patients, of which 184 patients with oncological diseases and 565 with non-oncological diseases, hospitalized at the level of Surgery II, Oradea County Emergency Clinical Hospital, between 15.03.2020 and 15.03.2021. We analyzed the cases of the department in terms of demographic data, oncological and non-oncological cases, comorbidities, types of interventions performed, type of hospitalization, length of hospitalization, mortality, care problems, using FOCG records, care plan and its annexes.

Results. 610 surgeries were performed in 749 patients, with an operability rate of $81 \%$. 151 surgeries were performed in the first 24 hours after hospitalization, with or without the result of the RT-PCR test for SARSCoV-2, representing $28 \%$ of cases, with additional protection measures and overloading of staff. Of the 184 patients with oncological diseases, 64 were hospitalized by appointment, breast cancer predominates and 120 cases by the emergency department, colorectal cancer predominates. The most common complications in non-oncological surgical cases were: acute cholecystitis with pancreatic reaction, angiocolitis, mechanical jaundice, perforated gallbladder with subhepatic abscess, gastric ulcer perforated with peritonitis, strangulated eventration with loop necrosis, check perforation, occlusions intestinal with severe hydroelectrolytic and metabolic imbalances, septic conditions. Patients with oncological effects presented complications such as: perforated colon cancer with fecal peritonitis, rectal cancer with anal stenosis and rectoria, gastric cancer with upper digestive hemorrhage, pancreatic cancer with mechanical jaundice, intestinal occlusion, esophageal cancer with complete stenosis, cachexia, severe nutritional and metabolic imbalances. Regarding comorbidities, the most common secondary diagnoses associated with the underlying disease were: cardiovascular disease, diabetes, endocrine disorders, neurological and/or psychiatric disorders, obesity, lung disorders.

Conclusions. The COVID-19 pandemic made surgical care more difficult due to the rules imposed, the number of hospitalizations decreased, patients delayed the operative moment, with a great impact on the subsequent evolution of the quality of life and survival. In addition to the specific problems of surgical emergencies and oncological cases, a problem for staff was the provision of preoperative and postoperative surgical care to patients with comorbidities such as neuro-mental disorders, metabolic diseases, obesity, diabetes, pathologies that increased risks and safety issues. In the context of the COVID-19 pandemic, the increase in the need for care led to the increase in the consumption of human and material medical resources.
\end{abstract}

Keywords: surgical pathology, comorbidities, care problems, COVID-19 pandemic 


\begin{abstract}
REZUMAT
Introducere. Activitatea desfăşurată într-o secţie de chirurgie generală este complexă, diversitatea cazuriIor şi comorbidități precum bolile cardiovasculare, tulburări neuro-psihice, boli metabolice, obezitate, diabet zaharat influenţează nevoile de îngrijiri ale pacienţilor. Aceste patologii cresc riscurile şi problemele legate de siguranţă, în contextul pandemiei COVID-19.

Material şi metodă. Am realizat un studiu retrospectiv descriptiv în care am inclus 749 pacienţi, dintre care 184 pacienţi cu afecţiuni oncologice şi $565 \mathrm{cu}$ afecţiuni nononcologice, internaţi la nivelul secţiei Chirurgie II, Spitalul Clinic Judeţean de Urgenţă Oradea, în intervalul 15.03.2020-15.03.2021. Am analizat cazuistica secţiei prin prisma datelor demografice, cazuri oncologice şi nononcologice, comorbidități, tipuri de intervenţii efectuate, tip de internare, durata spitalizării, mortalitate, probleme de îngrijiri, utilizând înregistrările din FOCG, Planul de îngrijiri şi anexele sale.

Rezultate. Au fost efectuate 610 intervenţii chirurgicale la 749 de pacienţi, cu un grad de operabilitate de $81 \%$. Au fost efectuate 151 intervenţii chirurgicale, în primele 24 ore de la internare, cu sau fără rezultat la testul RT-PCR pentru SARS-CoV-2, reprezentând $28 \%$ dintre cazuri, cu măsurile de protecţie suplimentare şi suprasolicitare a personalului. Dintre cei 184 pacienţi cu afecţiuni oncologice, 64 au fost internaţi prin programare, în care predomină cancerul mamar, şi 120 de cazuri prin serviciul de primiri urgenţă, în care predomină cancerul colorectal. Complicaţiile cele mai frecvente la cazurile chirurgicale nononcologice au fost reprezentate de: colecistita acută cu reacţie pancreatică, cu angiocolită, cu icter mecanic, colecist perforat cu abces subhepatic, ulcer gastric perforat cu peritonită, eventraţie strangulată cu necroză de ansa, perforaţie de cec, ocluzii intestinale cu dezechilibre hidroelectrolitice şi metabolice severe, stări septice. Pacienţii cu afecțiuni oncologice au prezentat complicaţii precum: cancer de colon perforat cu peritonită fecaloidă, cancer de rect cu stenoză anală şi rectoragie, cancer gastric cu hemoragie digestivă superioară, cancer de pancreas cu icter mecanic, ocluzie intestinală, cancer esofagian cu stenoză completă, caşexie, dezechilibre nutriţionale şi metabolice severe. În ceea ce priveşte comorbiditățile, cele mai frecvente diagnostice secundare asociate bolii de bază au fost: bolile cardiovasculare, diabetul zaharat afecţiuni endocrine, afecţiuni neurologice şi/sau psihiatrice, obezitate, afecţiuni pulmonare.

Concluzii. Pandemia COVID-19 a îngreunat îngrijirile chirurgicale prin regulile impuse, a scăzut numărul internărilor, pacienţii au întârziat momentul operator, cu impact mare asupra evoluţiei ulterioare a calităţii vieţii şi a supravieţuirii. Pe lângă problemele specifice urgențelor chirurgicale şi cazurilor oncologice, o problemă pentru personal a fost acordarea îngrijirilor chirurgicale preoperatorii şi postoperatorii pacienţilor cu comorbidități precum tulburări neuro-psihice, boli metabolice, obezitate, diabet zaharat, patologii care au crescut riscurile şi problemele legate de siguranţă, în contextul pandemiei COVID-19, creşterea necesarului de îngrijiri, a dus la creşterea consumului de resurse medicale umane şi materiale.
\end{abstract}

Cuvinte cheie: patologie chirurgicală, comorbidități, probleme de îngrijiri, pandemie COVID-19

\section{INTRODUCERE}

Răspândirea pandemiei COVID-19 a declanșat o criză sanitară, socială și economică globală complexă și profundă. Trăim într-o perioadă în care activitatea medico-chirurgicală şi îngrijirea pacienţilor cu afecţiuni chirurgicale şi oncologice se desfăşoară între reglementări internaţionale, reglementări interne, ordonanţe de urgență, legi, hotărâri ale Consiliului Naţional pentru Situaţii de Urgenţă, ale Ministerului Sănătăţii, ale CNAS, definiţii de caz, ghiduri şi protocoale de lucru privind supravegherea infecţiei cu SARS-CoV-2 şi ghiduri, protocoale de lucru şi recomandări ale societăţilor de profil chirurgical (1) şi oncologic (2).

Pacientul oncologic necesită o abordare pluridisciplinară (3), iar, în contextul pandemiei COVID-19, bolnavii de cancer sunt mai vulnerabili faţă de infecţiile virale de tip gripal (4), iar riscurile la care sunt supuşi aceşti pacienţi sunt mai mari decât la ceilalţi pacienţi. Pacienţii oncologici se află la risc vital ca urmare a afecţiunii de fond şi din cauza ameninţării infectării cu COVID-19, fiiind expuşi unui dublu risc (5).

La începutul pandemiei COVID-19, procedurile medicale elective (1), care nu au fost considerate urgente, inclusiv screening-ul cancerului, au fost în mare măsură suspendate, pentru a stabili priorităţile nevoilor urgente şi pentru a reduce riscul de răspândire a infecţiei COVID-19. În timpul stării de urgenţă, impusă de autorităţi, au fost evaluate şi tratate chirurgical numai cazurile care reprezentau urgenţe. După relaxarea măsurilor, mulţi pacienţi au evitat să-şi facă investigaţiile necesare de teama unei posibile infectări sau au întârziat prezentarea la medic în vederea rezolvării problemei chirurgicale (6), ceea ce a dus la apariţia complicaţiilor preoperatorii şi postoperatorii, $\mathrm{cu}$ impact negativ asupra evoluţiei ulterioare a pacientului şi, implicit, asupra calităţii vieţii.

\section{OBIECTIVE}

Prezenta lucrare îşi propune să abordeze o analiză retrospectivă a cazurilor internate la nivelul secţiei Chirurgie II din Spitalul Clinic Judeţean de Urgenţă Oradea, la care s-au efectuat intervenţii chirurgicale, cazuri oncologice şi nononcologice între 15.03.2020 și 15.03.2021, tipuri de intervenţii efectuate, comorbidități asociate, problemele de îngrijire a pacienţilor cu afecţiuni oncologice în preoperator şi postoperator, necesarul de îngrijiri, într-un an în care activitatea medico-chirurgicală şi 
îngrijirile acordate pacienţilor oncologici au fost influenţate de efectele pandemiei COVID-19.

\section{MATERIAL ŞI METODĂ}

Am realizat un studiu retrospectiv descriptiv în care am inclus 749 pacienţi, dintre care 184 pacienţi oncologi şi 565 nononcologici. Am analizat cazuistica secţiei prin prisma datelor demografice, cazuri oncologice şi nononcologice, comorbidități, tipuri de intervenţii efectuate, tip de internare, durata spitalizării, mortalitate, probleme de îngrijiri, datele fiind culese din înregistrările letrice şi electronice ale FOCG, Planul de îngrijiri elaborat prin evaluarea celor 14 nevoi fundamentale, modelul conceptual al Virginei Henderson (7), pentru a evidenţia nivelul de dependență, particularităţile problemelor de îngrijiri, în contextul pandemiei COVID-19.

\section{REZULTATE}

$\mathrm{Au}$ fost efectuate 749 internări, pacienţi cu afecţiuni oncologice şi nononcologice, 377 pacienţi din mediu rural şi 372 din mediu urban.

TABEL 1. Repartiția pe sexe şi pe mediul de proveniență

\begin{tabular}{|c|c|c|c|}
\hline \multicolumn{2}{|c|}{ Rural total 377 } & \multicolumn{2}{c|}{ Urban total 372 } \\
\hline Bărbați & Femei & Bărbați & Femei \\
\hline 187 & 190 & 189 & 183 \\
\hline
\end{tabular}

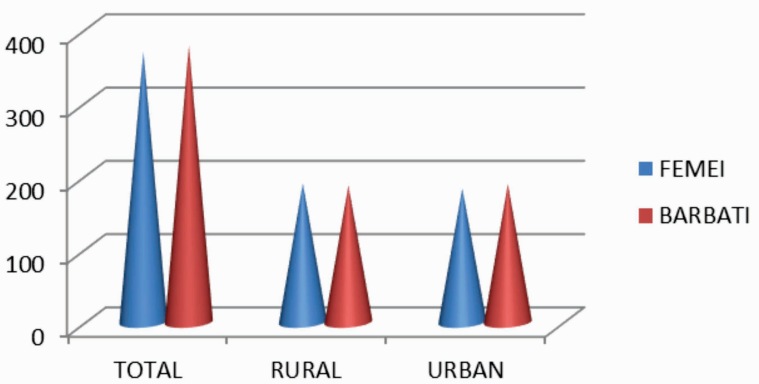

FIGURA 1. Repartiția pe sexe şi pe mediul de proveniență

Procentual, repartizarea pe sexe este aproximativ egală, cu 376 cazuri bărbaţi (50,2\%) și 373 cazuri femei $(49,8 \%)$.

$\mathrm{Au}$ fost efectuate 610 intervenţii chirurgicale la 749 de pacienţi, cu un grad de operabilitate de $81 \%$.
Au fost efectuate 163 intervenţii chirurgicale în primele 24 ore de la internare, cu sau fără rezultat la testul RT-PCR pentru SARS-CoV-2, reprezentând $28 \%$ dintre cazuri, cu măsurile de protecţie suplimentare necesare pentru siguranţa personalului, cu consum de resurse umane şi materiale mare, multe intervenţii desfăşurându-se cu dificultate din cauza echipamentului de protecţie suplimentară.

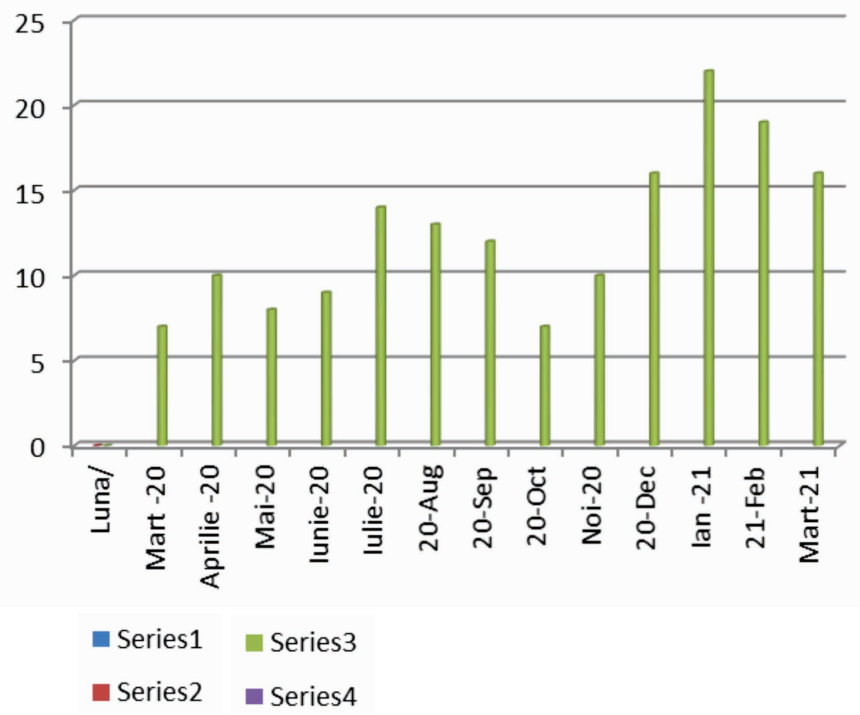

FIGURA 2. Intervenții chirurgicale efectuate în primele 24 de ore

Există o creştere a numărului de cazuri la care s-a practicat intervenţia chirurgicală în urgenţă în primele 24 ore de la internare, în lunile decembrie 2020, ianuarie 2021, februarie 2021, aferentă cazuisticii specifice urgenţelor chirurgicale. Se poate observa evoluţia în dinamică a numărului de cazuri la care s-a practicat intervenţia în urgență, cu o creştere în lunile decembrie 2020, ianuarie 2021, februarie 2021, aferenta cazuisticii specifice urgentelor chirurgicale, dar şi corelată cu o perioadă de regresie a pandemiei COVID-19 în România, aferentă acestor luni.

Au fost internaţi având ca diagnostic principal o afecţiune oncologică 184 pacienţi, reprezentând $24,5 \%$ din totalul internărilor efectuate, cu un procent mare din numărul total al internărilor.

Odată cu instalarea restricţiilor impuse de starea de urgență, în contextul pandemiei COVID-19, nu au mai fost efectuate internări programate. În luna aprilie, mai, iunie 2020, nu s-a efectuat nicio

TABEL 2. Intervenții chirurgicale efectuate în primele 24 de ore

\begin{tabular}{|c|c|c|c|c|c|c|c|c|c|c|c|c|c|c|}
\hline $\begin{array}{l}\text { Luna/ } \\
2020,2021\end{array}$ & $\begin{array}{c}\text { Mart } \\
-20\end{array}$ & $\begin{array}{c}\text { Aprilie } \\
-20\end{array}$ & Mai-20 & Iunie-20 & Iulie-20 & $\begin{array}{l}\text { Aug- } \\
20\end{array}$ & $\begin{array}{c}\text { Sep- } \\
20\end{array}$ & $\begin{array}{c}\text { Oct- } \\
20\end{array}$ & $\begin{array}{c}\text { Noi- } \\
20\end{array}$ & $\begin{array}{l}20- \\
\text { Dec }\end{array}$ & $\begin{array}{l}\text { Ian } \\
-21\end{array}$ & $\begin{array}{l}\text { Feb } \\
-21\end{array}$ & Mart-21 & Total \\
\hline $\begin{array}{l}\text { Intervenții în } \\
\text { primele } 24 \mathrm{~h}\end{array}$ & 7 & 10 & 8 & 9 & 14 & 13 & 12 & 7 & 10 & 16 & 22 & 19 & 16 & 163 \\
\hline
\end{tabular}


internare programată, până în luna iulie, când s-au reluat internările programate pentru pacienţii oncologici, cazuri elective, aflate în secvenţa terapeutică chirurgicală sau care necesitau o procedură pentru confirmarea diagnosticului oncologic. De asemenea, au fost suspendate spitalizările de zi prin care se efectuau diferite proceduri utilizate pentru diagnosticarea afecţiunilor oncologice.

Din totalul pacienţilor internaţi pentru afecţiuni oncologice, 64 au fost internaţi prin programare, reprezentând 34,8\%, cazuri elective aflate în secvenţa terapeutică chirurgicală şi pentru confirmare diagnostic, şi 120 de cazuri cu prezentare în serviciul de primiri urgenţe pentru complicaţii ale bolii oncologice, ocluzie intestinală, perforaţie, peritonită, hemoragie scădere ponderală, caşexie, imposibilitatea alimentării, dispnee, dureri abdominale, disfagie, reprezentând $65,2 \%$ din totalul cazurilor oncologice.

Din numărul total de cazuri oncologice internate, 102 cazuri sunt afecţiuni ale femeilor. Au fost înregistrate mai multe cazuri la femei, dată fiind şi exclusivitatea legată de sex pentru cancerul ovarian, uterin, mamar, reprezentând 55,4\% dintre cazuri. Au existat 82 de cazuri la pacienţi de sex masculin, reprezentând 44,6\% dintre cazuri, aici nefiind cuprinsă patologia sferei uro-genitale masculine, care nu se adresează serviciului de chirurgie generală.

Din totalul de 184 cazuri oncologice, la 162 pacienţi s-a practicat intervenţie chirurgicală, cu un grad de operabilitate de $88 \%$ la cazurile oncologice.

Repartiţia cazurilor oncologice în funcţie de localizare, la care s-a practicat o intervenţie chirurgicală, arată o predominanţă a cancerului eso-gastric şi colorectal la bărbaţi, iar la femei predomină cancerul mamar.

Numărul total de pacienţi de sex masculin la care s-a efectuat intervenţie chirurgicală este de 78 , comparativ cu 84 paciente cu afecţiune oncologică la care s-a practicat o intervenţie chirurgicală.

$\mathrm{Au}$ fost efectuate următoarele tipuri de intervenţii chirurgicale:

- pentru stabilirea diagnosticului de certitudine: biopsie cu ac, biopsie excizională, excizie tumorală, laparoscopie de stadializare

- terapeutice: intervenţii chirurgicale radicale sau chirurgie conservatoare

- paliative: derivaţii interne, stomie, citoreducţie tumorală, laparatomie, laparoscopie exploratorie

În ceea ce priveşte comorbidităţile, cele mai frecvente diagnostice secundare asociate bolii de bază se prezintă astfel: boli cardiovasculare, diabet zaharat, afecţiuni endocrine, afecţiuni neurologice şi/sau psihiatrice, obezitate, afecţiuni pulmonare.

Bolile cardiovasculare frecvent întâlnite atât la pacienţii cu afecţiuni oncologice, cât şi la cei cu afecţiuni nononcologice au fost: hipertensiunea arterială, insuficienţa mitrală aortică, insuficienţa cardiacă congestivă, blocul de ramură, angina pectorală, infarctul miocardic vechi, arteriopatia cro-

TABEL 3. Repartiția cazurilor oncologice, în funcție de localizare (la care s-a practicat intervenție chirurgicală)

\begin{tabular}{|c|c|c|c|c|c|c|c|c|c|}
\hline $\begin{array}{c}\text { Localizare/ } \\
\text { Sex }\end{array}$ & $\begin{array}{c}\text { Cancer } \\
\text { eso-gastric }\end{array}$ & $\begin{array}{l}\text { Cancer } \\
\text { colon }\end{array}$ & $\begin{array}{l}\text { Cancer } \\
\text { de rect }\end{array}$ & $\begin{array}{c}\text { Alte cancere } \\
\text { faringian, laringian, } \\
\text { splina }\end{array}$ & $\begin{array}{c}\text { Cancer } \\
\text { pancreas }\end{array}$ & $\begin{array}{l}\text { Cancer } \\
\text { ovarian }\end{array}$ & $\begin{array}{l}\text { Cancer } \\
\text { uterin }\end{array}$ & $\begin{array}{l}\text { Cancer } \\
\text { mamar }\end{array}$ & $\begin{array}{l}\text { Total } \\
\text { cazuri }\end{array}$ \\
\hline Femei & 5 & 21 & 6 & 8 & 1 & 11 & 11 & 20 & 84 \\
\hline Barbati & 19 & 23 & 11 & 14 & 10 & 0 & 0 & 0 & 78 \\
\hline Total & 44 & 47 & 17 & 22 & 12 & 11 & 11 & 20 & 162 \\
\hline
\end{tabular}

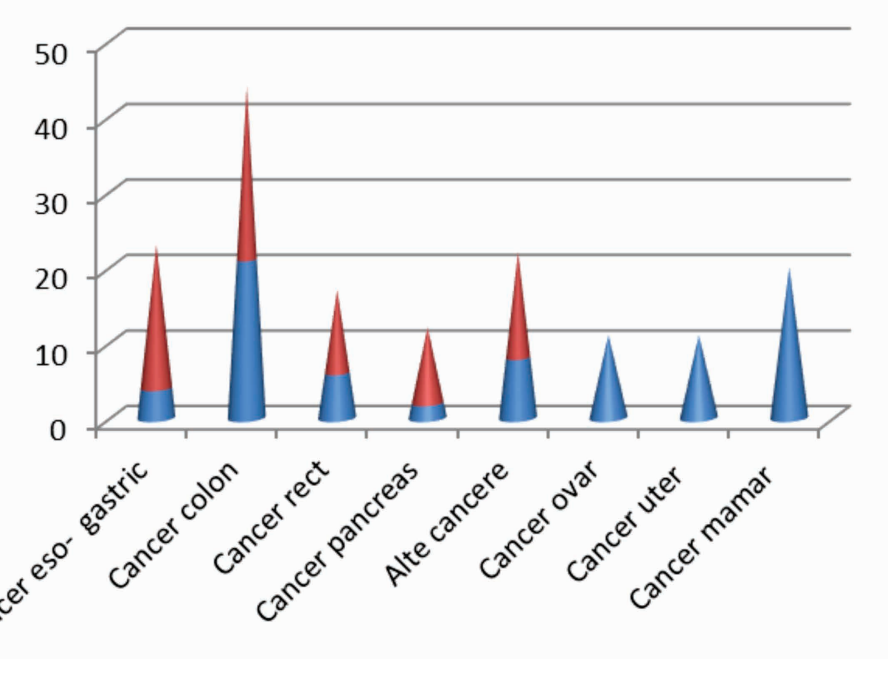

Barbati

Femei
FIGURA 3. Repartiția cazurilor oncologice, in funcție de localizare (la care s-a practicat intervenție chirurgicală) 
TABEL 4. Repartiția principalelor diagnostice secundare

\begin{tabular}{|c|c|c|}
\hline Nr. crt . & Diagnostice secundare & Număr cazuri \\
\hline 1. & Boli cardiovasculare & 300 \\
\hline 2. & Obezitate & 282 \\
\hline 3. & Afecţiuni pulmonare & 131 \\
\hline 4. & Diabet zaharat, afecţiuni endocrine & 118 \\
\hline 5. & $\begin{array}{c}\text { Afecţiuni neurologice şi/sau } \\
\text { psihiatrice }\end{array}$ & 80 \\
\hline \multicolumn{2}{|c|}{} \\
\hline
\end{tabular}

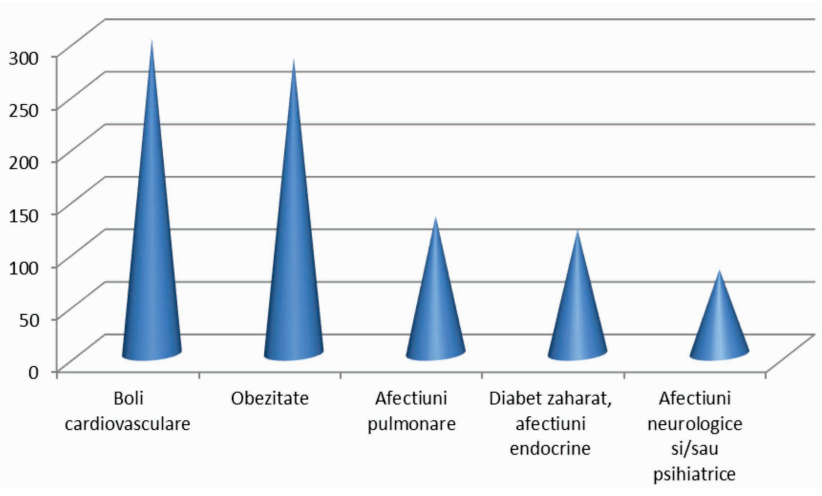

FIGURA 4. Repartiția principalelor diagnostice secundare

nică obliterantă, angiopatia, insuficienţa venoasă cronică. Afecţiunile endocrine au fost în mare parte reprezentate de diabetul zaharat de tip 1 şi 2, cu complicaţiile lui (angiopatia diabetică, nefropatia diabetică), care au necesitat monitorizare atentă şi îngrijiri susţinute.

Suferinţa neurologică şi psihică, cu afectare uşoară până la severă, este reprezentată de sechele ale accidentelor vasculare, deficitul cognitiv, demența senilă, boala Alzheihmer, depresia, tentativa de suicid, sevrajul, cazuri care au suprasolicitat personalul, necesarul de îngrijiri al pacienţilor $\mathrm{cu}$ aceste afecţiuni asociate patologiei chirurgicale fiind crescut.

Pacienţii cu diverse grade de obezitate, cu necesar de suplinire în realizarea nevoilor fundamentale, au creat o suprasolicitare fizică a personalului.

Afecţiunile pulmonare au fost reprezentate de boli acute asociate evoluţiei unei boli chirurgicale - pneumonia, pronhopneumonia, pleurezia, insuficienţa respiratorie acută postoperatorie -, dar şi de boli cronice - astmul bronşic, bronhopneumopatia cronică obstructivă, silicoza - care s-au acutizat postoperator.

Complicaţiile pulmonare, alături de starea septică şi insuficienţa pluriorganică, au fost diagnostice secundare la cazurile decedate.

Bronhopneumonia cu modificări caracteristice de sticlă mată a fost prezentă la 8 dintre cele 15 cazuri care au fost depistate ca pozitive pentru SARS-CoV-2, internate pe secţie.
Principalele probleme de îngrijiri atât în preoperator, cât şi în postoperator sunt anxietatea crescută legată de incertitudinea diagnosticului, distresul legat de boala oncologică, teamă infectării cu SARS-CoV-2, creşterea dependenţei de îngrijiri legate de particularitatea intervenţiei chirurgicale, afectarea circulaţiei, risc de sângerare, dificultăţi de mobilizare, de îmbrăcare, risc infecţios, risc de complicaţii, risc de deces postoperator.

$\mathrm{O}$ parte dintre pacienţii cu afecţiuni nononcologice s-au prezentat în faza de evoluţie cu complicaţii a unei boli chirurgicale precum: colecistită acută cu reacţie pancreatică, cu angiocolită, cu icter mecanic, colecist perforat cu abces subhepatic, ulcer gastric perforat, cu peritonită, eventraţie strangulată cu necroză de ansă, perforaţie de cec, ocluzii intestinale cu dezechilibre hidroelectrolitice şi metabolice severe, cu stări septice.

Pacienţii cu afecţiuni oncologice au prezentat complicaţii precum: cancer de colon perforat $\mathrm{cu}$ peritonită fecaloidă, cancer de rect cu stenoză anală şi rectoragie, cancer gastric cu hemoragie digestivă superioară, cancer de pancreas cu icter mecanic, ocluzie intestinală, caşexie, dezechilibre nutriţionale şi metabolice severe. Au existat şi cancere la care internarea s-a făcut într-un stadiu avansat al bolii, fiind temporizată internarea de către pacient, deşi semnele erau sugestive pentru o neoplazie.

Începând cu luna iulie 2020, s-au reluat internările pentru pacienţii oncologici fie pentru efectuarea unei proceduri diagnostice, fie pentru efectuarea unei intervenţii elective, ţinând cont şi de recomandările societăţilor de profil. Nu s-au efectuat spitalizări de zi, a scăzut numărul pacienţilor internaţi pentru diagnosticarea unei afecţiuni potenţial maligne.

Prezentarea pacienţilor în serviciul spitalicesc cu complicaţii asociate afecţiunilor chirurgicale şi oncologice a dus la spitalizări prelungite, cu alterarea indicatorilor de calitate a serviciilor medicale, durata de spitalizare, rata de ocupare a paturilor, mortalitatea. Durata medie de spitalizare a fost de 6 zile, în comparaţie cu 5 zile în 2019, rata de ocupare a paturilor fiind de $50 \%$, mult mai scăzută faţă de anul 2019, când era o rată de ocupare a paturilor de $74-80 \%$, după cum arată rapoartele statistice ale spitalului.

55 pacienţi au avut în cursul acestei perioade de pandemie reinternări pe secţii chirurgicale sau pe alte secţii ale spitalului, pentru patologia chirurgicală sau pentru o patologie asociată.

S-au aplicat măsurile sanitare în contextul epidemiologic actual: purtarea echipamentului de 
protecţie de către întreg personalul secţiei, triajul epidemiologic al personalului, testarea periodică a întregului personal şi izolarea personalului pozitiv la domiciliu, triajul epidemiologic şi testarea pacienţilor la internare prin test RT-PCR pentru SARSCoV-2, internarea pacienţilor în salon tampon până la primirea rezultatului testelor pentru SARS$\mathrm{CoV}-2$ şi izolarea pacienţilor pozitivi.

Ingrijirile care trebuiesc acordate în contextul pandemiei COVID-19 sunt complexe, personalul trebuie să facă faţă unei duble solicitări, solicitării care vine din partea pacientului şi solicitării existente în contextul actual al pandemiei COVID-19.

În toată această perioadă, numărul pacienţilor confirmaţi pozitiv pentru SARS-CoV-2 la nivelul secţiei a fost de 15, dintre care 6 pacienţi au fost rezolvaţi chirurugical şi ulterior au fost transferaţi la Spitalul Municipal Oradea, transformat în spital COVID.

Numărul personalului care s-a pozitivat la nivelul secţiei Chirurgie II a fost de 19 din 33 persoane, cu un procent de persoane pozitivate pentru SARSCoV-2 de 57,5\%.

$\mathrm{Nu}$ s-a înregistrat la nivelul secţiei niciun deces din rândul pacienţilor pozitivaţi.

\section{DISCUTुII}

În acest an de pandemie COVID-19, la nivelulul secţiei noastre, s-a produs o reducere a numărului de internări faţă de anul 2019 în medie cu 40\%. La nivel naţional, există un studiu al impactului pandemiei COVID-19 asupra accesului la servicicile de sănătate a pacienţilor cronici, care confirmă o scădere cu $46 \%$ a internărilor pacienţilor cu afecţiuni oncologice în anul 2020 faţă de anul 2019 (8).

Gradul de operabilitate este mare la pacienţii internaţi, de $81 \%$ în perioada analizată în studiul nostru, faţă de de 75\%în anul 2019. Există un studiu retrospectiv, publicat în februarie 2021, în care este analizată activitatea chirurgicală într-o secţie de chirurgie generală în Anglia, în prima lună de pandemie COVID-19, unde gradul de operabilitate al pacienţilor internaţi este de 33\% (9).

Am înregistrat o rată mare a mortalităţii de $6,5 \%$, cu 49 decese, faţă de o rată a mortalităţii cu o medie anuală în 2019 de 2,5\%, explicată prin numărul mare de cazuri la care prezentarea s-a făcut în urgenţă pentru complicaţii precum perforaţie, hermoragie, ocluzie intestinală, deficite nutriţionale, dezechilibre electrolitice şi metabolice severe, întârzierea momentului operator în contextual pandemiei COVID-19. Aceste date pot fi corelate cu rezultatele unui studiu retrospectiv al activităţii chirurgicale, realizat în Spania, publicat în februarie 2021 şi care arată o creştere a morbidităţii și mortalităţii postoperatorii, datorate întârzierii momentului operator, din cauză că teama de contagiune COVID-19 a întârziat consultaţia iniţială şi momentul diagnosticarii în perioada pandemiei COVID-19 (10).

Teama de infectare virală a influențat diagnosticul și tratamentul cancerului colorectal, cu afectarea rezultatelor chirurgicale și oncologice, fapt menţionat şi în rezultatele unui studiu realizat în Coreea şi publicat în mai 2021 (11).

Întreruperea spitalizărilor de zi şi a screeningului pentru afecţiunile oncologice (12) împiedică depistarea într-un stadiu iniţial al bolii, întârzierea efectuării intervenţiei chirurgicale în moment optim ar putea duce la creşterea numărului de decese aferente patologiei oncologice în următorii ani (13), în special în cazul cancerului mamar (14), unde, din cauza neefectuării screening-ului, diagnosticarea se realizează într-o fază avansată a bolii (15).

\section{CONCLUZII}

A scăzut numărul de cazuri internate în contextul pandemiei COVID-19 ca urmare a reglementărilor legislative, care au limitat numărul internărilor, iniţial cu $80 \%$ ulterior cu $50 \%$, scăderii adresabilităţii din cauza fricii pacienţilor de a nu contacta COVID-19, panicii create în rândul personalului.

Asupra patologiei oncologice, pandemia COVID-19 a avut următoarele implicaţii: amânarea diagnosticării precoce, amânarea momentului chirurgical la cazurile elective care se aflau în secvenţa chirurgicală, prezentarea pacienţilor în serviciul de primiri urgențe cu complicaţii ale cancerului ca boala de bază, cu influența negativă asupra supravieţuirii pe termen lung.

Pacienţii cu afecţiuni nononcologice au întârziat momentul operator, prezentarea în vederea internării pentru o parte dintre aceştia s-a făcut în faza de complicaţie a bolii, cu consecințe negative asupra morbidităţii şi mortalităţii postoperatorii, aceste complicaţii fiind diagnostice secundare la pacienţii decedaţi.

Pe lângă problemele specifice urgențelor chirurgicale şi cazurilor oncologice, o problemă pentru personal a fost acordarea îngrijirilor chirurgicale în contextul pandemiei COVID-19 pacienţilor cu comorbidități precum tulburări neuro-psihice, boli metabolice, obezitate, diabet zaharat, patologii care au crescut scorul şi nivelul de dependenţă 
la aceşti pacienţi, riscurile şi problemele legate de siguranţă.

Regulile impuse în contextul pandemiei COVID-19 și lipsa familiei ca suport în procesul

Conflict of interest: none declared

Financial support: none declared

\section{BIBLIOGRAFIE}

1. COVID-19: Elective Case Triage Guidelines for Surgical Care. Available at: https://www.facs.org/covid-19/clinical-guidance/ elective-case.

2. Curigliano G, Cardoso MJ, Poortmans P, Gentilini O, et al.; editorial board of The Breast. Recommendations for triage, prioritization and treatment of breast cancer patients during the COVID-19 pandemic. Breast. 2020 Aug;52:8-16.

3. Croke JM, El-Sayed S. Multidisciplinary management of cancer patients: chasing a shadow or real value? An overview of the literature. Curr Oncol. 2012 Aug;19(4):e232-8.

4. Societatea Naţională de Oncologie Medicală din România (SNOMR). Măsuri recomandate în vederea reducerii impactului pandemiei COVID-19 asupra pacienţilor oncologici şi asupra serviciilor de oncologie. Available at: https://snomr.ro/masuri-recomandatereducerii-impactului-pandemiei-covid-19-asupra-pacientiloroncologici-asupra-servicillor-de-oncologie/.

5. Davide M. General considerations for cancer patients during the COVID-19 pandemic. Available at: https://ecpc.org.

6. Kibbe MR. Surgery and COVID-19. JAMA. 2020;324(12):1151-1152.

7. Henderson VA. The nature of nursing. A definition and its implications for practice, research, and education. Reflections after 25 years. NLN Publ. 1991 Nov;(15-2346):vii-xi, 1-116.

8. Impactul pandemiei COVID-19 asupra accesului bolnavilor cronici la servicii medicale Raport publicat de Fundația Romanian Angel Appeal - Apelul Îngerului Român și Observatorul Român de Sănătate. Septembrie 2020.

9. Callan R, Assaf N, Bevan K. Impact of the COVID-19 Pandemic on Acute General Surgical Admissions in a District General Hospital in terapeutic au scăzut calitatea vieţii acestor pacienţi, au crescut nivelul de dependenţă şi necesarul de îngrijiri, ducând la creşterea consumului de resurse medicale umane şi materiale.

the United Kingdom: A Retrospective Cohort Study. Surg Res Pract. 2020 Aug 12;2020:2975089.

10. Zoilo M, Javier O, Aurema O, Sebastiano B, Sebastian V. Postoperative complications and mortality following emergency digestive surgery during the COVID-19 pandemic:A multicenter collaborative retrospective cohort study protocol (COVID-CIR). Medicine (Baltimore). 2021 Feb 5;100(5):e24409.

11. Choi JY, Park IJ, Lee HG, Cho E, et al. Impact of the COVID-19 Pandemic on Surgical Treatment Patterns for Colorectal Cancer in a Tertiary Medical Facility in Korea. Cancers (Basel). 2021 May 6;13(9):2221.

12. Vissio E, Falco EC, Collemi G, Borella F, Papotti M, Scarmozzino A, Cassoni P, Bertero L. Impact of COVID-19 lockdown measures on oncological surgical activity: Analysis of the surgical pathology caseload of a tertiary referral hospital in Northwestern Italy. J Surg Oncol. 2021 Jan;123(1):24-31.

13. Curigliano G, Banerjee S, Cervantes A, Garassino MC, et al.; Panel members. Managing cancer patients during the COVID-19 pandemic: an ESMO multidisciplinary expert consensus. Ann Oncol. 2020 Oct;31(10):1320-1335.

14. Breastcancer.org. Special Report: COVID-19's Impact on Breast Cancer Care. October 19, 2020

15. Maringe C, Spicer J, Morris M, Purushotham A, Nolte E, Sullivan R, Rachet B, Aggarwal A. The impact of the COVID-19 pandemic on cancer deaths due to delays in diagnosis in England, UK: a national, population-based, modelling study. Lancet Oncol. 2020 Aug; 21(8):1023-1034. 